\title{
A Study on Digital Games Internet Addiction, Peer Relationships and Learning Attitude of Senior Grade of Children in Elementary School of Chiayi County
}

\author{
Shu-Min Tsai ${ }^{1}$, Yaw-Yih Wang ${ }^{1} \&$ Chih-Miao Weng ${ }^{2}$ \\ ${ }^{1}$ Department of International Business at Central Taiwan University of Science and Technology, Taiwan \\ ${ }^{2}$ Chiayi County Nan Sing Elementary school, Taiwan \\ Correspondence: Yaw-Yih Wang, Department of International Business at Central Taiwan University of Science \\ and Technology, Taiwan. E-mail: a0928994199@gmail.com
}

Received: January 17, 2020 Accepted: March 1, 2020 Online Published: March 23, 2020

doi:10.5539/jel.v9n3p13 URL: https://doi.org/10.5539/jel.v9n3p13

\begin{abstract}
The study explored the relationships between digital games internet addiction, peer relationships, and learning attitudes through questionnaire survey in senior grade of elementary school children in elementary school in Chiayi County. Taking 735 students as the research object, SPSS 22.0 as a quantity research analysis instrument was applied to launch descriptive statistics, t-test, and single factor variation analysis, Pearson Product Difference Correlation Analysis, and Stepwise Multiple Regression Analysis. The research results found that 93.2\% of high-grade students in Chiayi County played digital games 2 to 3 times a week, and those who took less 1 hour to play digital games. The addiction level of digital internet games for schoolchildren, peer relationships and learning attitude ranked upper-middle level. There are obvious differences in digital gaming internet addiction, peer relationships, and learning attitudes among various background variables such as "school location", "weekly use" and "daily use time". Gaming internet addiction has a low degree of negative correlation in both peer relationships and learning attitudes, while the peer relationships has a moderately positive relation with learning attitudes. Peer-to-peer relationships may be highly predictive of learning attitudes. This research focuses on the educational problems of digital game internet addiction that primary school teachers are most likely to face. It explores the relationship between peer relationships and learning attitudes, fills in the current lack of research, and draws the above important findings. It is suggested that it can be used as an important reference for teachers, parents and follow-up researchers, and contribute to the academic research of primary education in Taiwan.
\end{abstract}

Keywords: senior grade of students in elementary school, digital games internet addiction, peer relationship, learning attitude

\section{Introduction}

Owing to technology altering from day to day and the booming development of the internet, it has changed people's living habits and consumption patterns. According to the 2017 National Development Commission's Internet Addiction Research Report, it indicated that internet access behaviors, whether a risk group for internet addiction or not, they used smart-phones as the online access leisure device, the research found that internet addiction risk group those who played games $(34.0 \%)$, watched videos $(33.4 \%)$, or operated the internet social community (28.7\%) also had higher ratios than those who were not addicted to the internet. In the "2018 Taiwan Internet Report" of the Taiwan Internet Information Center, a consortium of corporations, it was found that the internet access rate for all the 12 to 49 years old was over $90 \%$, and $41.6 \%$ of the respondents "played online games/mobile games", and men are significantly higher than women, and the age is 12 to 29 years, and the usage rate is higher than other age groups. It also found that the age group playing online games has fallen to senior grade of elementary school; internet access is widespread. Ye Zhi-Hang (2011) mentioned that the external motivation of students to participate in games was attracted by games, and the internal motivation was to kill time as getting bored. It can be known that digital games have become an important activity for school children in daily life. Therefore, this is the priority motivation to research if it has become an internet addiction for further discussion. 
The sound and light effects of digital games, rewards, promotion, and realistic and interesting pictures and challenging enable to satisfy the sense of accomplishment in the minds of children, achieve the entertainment effect and kill time, so it has become one of children leisure activities nowadays. Tsai, Cheng-Hsuan (2011) indicated that excessive play is easy to indulge, which leads to low learning motivation. Weng, Ching-Yen (2014) also proposed that online games will negatively affect physical and mental health and learning attitudes. In addition, Hsiao, Shih-Liang (2019) proposed that there was a negative correlation between real interpersonal relationships and internet addiction, and Shih, Yu-Heng (2019) found that there was a positive correlation between internet addiction and mental health performance, Huang, Yu-Hsun (2017) found that internet addiction has significant effects on parent-child relationships, peer relationships, and interpersonal relationships. Because senior grade of children are in the early phase of their teens, they regard peer relationships as the most important in interpersonal relationships, which inspires to profound thought in this research for further exploring the relationships between games and peer attitudes using digital games for senior grade of students. This is the second motivation.

In addition, the current relevant research is mainly based on online games and website games. However, in accordance with modern trends, games have been developed various models. For example, play games with on televisions, computers, and mobile phones. This research is collectively referred to as digital games. There is still a gap in the study of learning attitude, which is worthy of in-depth exploration. This is the third motivation for research.

\section{Literature Reviews}

\subsection{Digital Games Internet Addiction}

\section{(1) Digital games}

Wu, Tai-Ling (2013) proposed digital games, which were designed and developed based on digital technology, and applied digital devices as platforms to provide games for the public. The digital games in the digital content industry mentioned in Kiwi Encyclopedia are provided by the information hardware platform for sound and light entertainment to the general consumers. According to the above literature, the digital games of this study is defined as "a product or service developed and designed with digital technology, providing sound and light entertainment to the general consumers, using information technology to develop or integrate games content." The digital games content in the research includes: TV Game, PC Game, Arcade Game, Handheld Game, and Mobile Game.

\section{(2) Internet addiction}

American psychiatrist Ivan Goldberg was the first to propose "Internet Addiction Disorder" (IAD). He cited the fourth edition of the American Psychiatric Association (1994) (Diagnostic and Statistical Manual of mental Disorders 4th ed. (DSM-IV) as a template, describing the symptoms of internet addiction as "the weakening of academic, work, schoolwork, social, family, physical, and psychological functions caused by excessive internet use". Next, American psychologist Young referred to internet-related symptoms as problematic internet use (PIU). This symptom is similar to impulse-control disorder and is the closest to the symptom of gambling. Young also proposed a more formal vocabulary-pathological internet use (PIU) and used this name to represent addictive internet use behavior. British psychologist Griffiths (1995) applied traditional clinical cases of addiction to study internet addiction and regard internet addiction as a technological addiction such as computer addiction, video addiction, and television addiction.), so internet addiction is also a type of technological addiction. The science and technology addiction mean the process of human-computer interaction, which belongs to non-chemical addiction. Science and technology addiction usually involve various temptations and continuous strengthening characteristics to attract people to indulge.

This research refers to the definition of internet addiction by domestic and foreign scholars and found that most foreign scholars have revised the fourth edition of the "Mental Disorder Diagnosis and Statistical Reference Manual" (DSM-IV) to define internet addiction. Goldberg (2016) identified three or more of the seven diagnostic criteria as long as at least 12 months; Young (1998) identified five or more of the eight diagnostic criteria. Griffiths (1995) refers to the six diagnostic criteria that have more than three symptoms; Anderson (2001) referred to the seven diagnostic criteria and three recognized in 12 months. In addition, for domestic scholars on internet addiction, Chen, Shu-Hui (2003) revised the Chinese Internet Addiction Scale (CIAS-R) in her research, which included psychological and behavioral characteristics. 1) Tolerance of internet addiction, 2) Compulsive internet use, 3) Withdrawal from internet addiction, 4) Internet addiction related problems. Domestic scholars Liu, Wen-Shang (2004), Tsai, Pei-Chi (2005), Chiu, Pin-Ying (2011) and other research on internet addiction found that school children use the internet to play games with digital devices, generate excessive dependence and 
require more time to satisfy their psychological pleasure, which is called digital games internet addiction. As mentioned above, the digital games internet addiction in this study is referred to Chen, Shu-Hui (2003) and mainly divided into five levels, compulsiveness, withdrawal, tolerance, time management and interpersonal problems.

\subsection{Peer Relationship}

Lewis and Rosenblum define peers as "people who have the same foothold with others" according to the Webster's Dictionary. Santrock (1988) indicated that "peers" are people at similar age, similar learning stage, and the same mature level. In the definition of peer relationship, Durki (1995) proposed that peer relationship is an individual-person relationship with others in terms of social status and cognitive ability. Berk (1997) pointed out that peer relationship is peers who have the same status and level and can share some abilities and goals together. Peer relationship in this research refers to classmates or friends of their own age who have influence, popularity, acceptance, and ability to share feelings in a group when they get along with each other.

The connotation of peer relations for scholars is different due to their research priorities. As Hartup (1983) mentioned in "Peer System", the relationship between peers is divided into four dimensions: interaction, partnership, imitation, popularity, and group status. Lin, Shih-Hsin (2000) issued self-assessment of peer relationship (imitation, friendship, social anxiety), and peer reviews of peer relationship (Sociometrist Index). Lu, Feng-Yu (2011) proposed three levels of self-concept, self-disclosure and group social [28]. Liu, Ming-Yi (2014) proposed friendship, identity imitation, and social skills.

To sum up, the peer relationship referred to in this research is a classmate or a friend of his or her age. As they get along with each other, they have the influence and popularity in the group, the degree of acceptance, and the ability to share moods. Refer to Lin, Shih-Hsin (2000) and analyze peer relationship on three levels: "group identity", "friendship" and "social anxiety."

\subsection{Learning Attitude}

In 1960, Rosenberg and Hovland proposed that attitudes consist of emotion, cognition and action. Chang, Chun-Hsing (1992) felt that attitude is the behavioral tendency of an individual to people in surrounding, things and environment, with his own cognition for like or dislike. In terms of the definition of learning attitude, Chin, Meng-Chun (1992) proposed to divide learning attitude into two categories: first, attitude to academic learning: students' motivation and interest in what they have learned. The other is the attitude towards the learning environment, that is, the students' subjective viewpoint caused by the surrounding environmental factors, such as the teacher's teaching attitude or peer interaction. Chang, Te-Jui (1997) indicated that learning attitude includes attitude towards things, such as attitude to courses, attitude to class, preparation of homework, attitude to examinations, and opinions on reading scope; attitude to schools include school activities, teachers, campus environment, school rituals, and identification with the school. To sum up, the learning attitude of in this research refers to the internal feelings and external behavior tendencies induced by the student's instructor, curriculum, and learning situation during the study process, such as agree, opposition, positive or negative reaction.

In addition, there are many researches by domestic scholars for the connotation of learning attitude. The findings of aggregation include the following aspects: learning motivation (Huang \& Chao-Kai, 1993; Huang \& Chi-Chun, 2006; Chen \& Shu-Lan, 2011; Chen \& Yi-Ya, 2015), learning methods (Huang \& Chao-Kai, 1993; Huang \& Qi-Jun, 2006; Liang \& Lian-Gyuan, 2007; Su \& Jun-Yuan, 2010), learning habits (Huang \& Qi-Jun, 2006; Su \& Jun-Yuan, 2010; Chen \& Shu-Lan, 2011), environmental attitudes (Liang \& Lian-Gyuan, 2007; Wu $\&$ Shu-Zhen, 2016), etc. To sum up, the connotation of learning attitude in this study is mainly based on the interpretation of the learning attitude connotation of Huang, Chao-Kai (1993), Liang and Lian-Gyuan (2007) and Huang and Qi-Jun (2006), "Learning habits", "learning methods", and "environmental attitudes."

\section{Methodology}

\subsection{Research Framework}

In accordance with the relevant literature, this research sequentially analyzes the differences between different personal background variables among senior schoolchildren digital games use, internet addiction, peer relationship, and attitude to learning. Addictions, peer relationship and learning attitude are related to each other, as shown in Figure 1. 


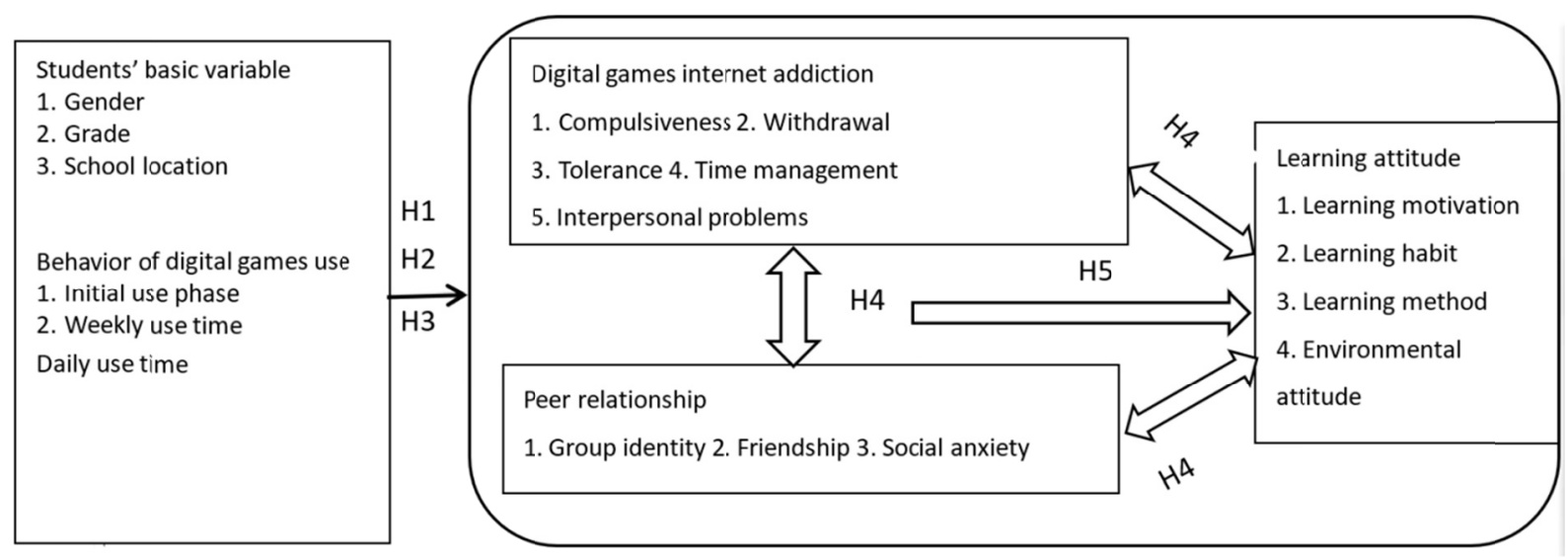

Figure 1. Research structure diagram

\subsection{Research Hypothesis}

The hypothetical framework to be tested in this study as follows:

Table 1. Contents of the hypothetical structure in this research

\begin{tabular}{ll}
\hline Assume & Content \\
\hline Assume 1 & $\begin{array}{l}\text { There are significant differences in digital addiction among senior children in different background variables } \\
\text { (including gender, grade, school location, weekly use time, and daily use time). }\end{array}$ \\
Assume 2 & $\begin{array}{l}\text { There are significant differences in peer relationship among senior children of different background variables } \\
\text { (including gender, grade, school location, number of weekly use time, and daily use time). }\end{array}$ \\
Assume 3 & $\begin{array}{l}\text { There were significant differences in learning attitude among senior children with different background variables } \\
\text { (including gender, grade, school location, weekly use time, and daily use time). }\end{array}$ \\
Assume 4 & $\begin{array}{l}\text { Elementary school senior children have significant correlations in digital games internet addiction, peer } \\
\text { relationship, and learning attitude. }\end{array}$ \\
Assume 5 & $\begin{array}{l}\text { Elementary school senior children have a predictive attitude towards learning in relationship between digital } \\
\text { addiction and peers in digital games. }\end{array}$ \\
\hline
\end{tabular}

\subsection{Research Object}

This study is for the senior students of grade 5 and grade 6 in elementary school of 105th year in Chiayi County. The pre-samples were sampled intentionally. The schools in the three districts of Shanhaitun, Chiayi County were selected from 1or 2 schools. The implementation was carried out for the upper grade of schoolchildren. A total of 250 questionnaires were rejected after the invalid questionnaires, and pretest analysis was performed. The formal test samples were intentionally sampled. A total of 15 schools in the three districts of Shanhaitun, Chiayi County were selected for formal questionnaire distribution. There were 608 paper questionnaires, 583 were collected, and 779 internet questionnaires were combined with 196.44 invalid questionnaires, a total of 735 valid questionnaires, and a recovery rate of $94.3 \%$.

\subsection{Research Tools}

This study adopted a questionnaire survey method, which was compiled with reference to scholars' questionnaires, and were adapted after reviewing and correcting the content validity by 9 experts. The questionnaire content has three levels, which are the "Digital Games Internet Addiction Scale" "," "Peer Relationship Scale" and "Learning Attitude Scale" scored on the Likert four-point scale, with "absolutely matched" being 4 points, "matched" being 3 points," not matched" being 2 points, "mostly not matched" being 1 point. The scale of this study was compiled as follows: 
Table 2. Contents and references of each scale in this study

\begin{tabular}{llll}
\hline Scale name & Facet name & $\begin{array}{l}\text { Number of facet } \\
\text { questions }\end{array}$ & Scale references \\
\hline Digital games internet & 1. Compulsive & 4 & 1. Chen, Shu-Hui et al. (2003) "Chinese Internet \\
addiction scale & 4 & Addiction Use Status Scale", \\
& 2. Withdrawal & 3 & 2. Huang, Se-Chuan (2011) "Internet Use Scale", \\
& 3. Tolerance & 5 & 3. Tsai, Cheng-Hsuan (2011) "Internet Addiction \\
& 4. Time management & Scale" \\
& 5. Interpersonal problems & 4 & 1. Lin, Shih-Hsin (2000) "Peer Relationship \\
Peer relationship Scale & 1. Group identification & 4 & Scale" \\
& 2. Friendship relationship & 6 & \\
& 3. Social Anxiety & 3 & 1.Huang, Chao-Kai (2003) "Learning Attitude \\
Learning atttitude scale & 1. Learning motivation & 5 & Scale", 2. Lin, Chien-Yu (2008) "Learning \\
& 2. Learning habit & 4 & Attitude Scale", 3. Huang, Chi-Chun (2006) \\
& 3. Learning method & 4 & "Learning Attitude Scale" \\
\hline
\end{tabular}

\subsection{Pre-Test Analysis}

In the pre-test analysis, the statistical software has been applied to process data reliability and validity analysis with SPSS 22.0 in this study, including item analysis, factor analysis, and reliability analysis. The criterion used in the project analysis is adopted Wu, Ming-Lung's advice (2016). The extreme value is used to determine the comparison of critical ratio $\geq 3.00$. The correlation between the item and the total score is $\geq .400$, the correlation between the corrected item and the total score is $\geq .400$, the deleted $\alpha$ value of the item in the homogeneity test $\leq$ the $\alpha$ coefficient of the internal consistency of the scale, the commonality $\geq .200$, the factor load $\geq .450$ as the basis for deleting or retaining the question. Finally, according to factor analysis and reliability analysis, the following scale content is obtained as shown in Table 3. Among them, the third aspect of social anxiety in the peer relationship scale was deleted in the pretest analysis owing to not meet the criteria.

\subsection{Data Processing and Analysis}

After the completion of the formal questionnaire test, review the response status and remove the incomplete or illogical questionnaires to proceed coding, and then apply the software SPSS22.0 for descriptive and inferential statistical analysis (including independent sample T test), One-way ANOVA, Pearson Correlation Coefficient Analysis and regression analysis).

Table 3. Contents of each scale after pre-test analysis

\begin{tabular}{lllll}
\hline Scale name & Facet name & $\begin{array}{l}\text { Facet } \\
\text { questions }\end{array}$ & $\begin{array}{l}\text { Cumulative explanatory } \\
\text { variation\% }\end{array}$ & $\begin{array}{l}\text { Overall scale } \\
\text { Cronbach 's } \alpha\end{array}$ \\
\hline Digital Games Internet & 1. Compulsive & 3 & 70.829 & .914 \\
Addiction Scale & 2. Withdrawal & 4 & & \\
& 3. Tolerance & 3 & & \\
& 4. Time management & 3 & & .875 \\
& 5. Interpersonal problems & 3 & \multirow{2}{*}{64.748} & \\
Peer Relationship Scale & 1. Group identification & 4 & & .885 \\
& 2. Relationships & 5 & 66.469 & \\
Learning Attitude Scale & 1. Learning motivation & 4 & & \\
& 2. Learning habits & 3 & & \\
& 3. Learning method & 3 & & \\
& 4. Environmental attitude & 3 & & \\
\hline
\end{tabular}

\section{Result and Discussion}

The formal questionnaires to be retrieved in this study are analyzed by the SPSS22.0 statistical software. The results are as follows:

\subsection{Basic Data Analysis}

This study analyzes the basic variables of school children: there are more males reaching at $51.2 \%$ than female $48.8 \%$ of students. The sixth grade of students are $51.3 \%, 48.7 \%$ in the fifth grade. The location of the school is $44.2 \%$ Tun District, the sea area is $42.2 \%$, and the mountain area is $13.6 \%$; the participation of school children in 
their own games is as high as $93.2 \%$. According to digital games use behavior variables, in the initial use phase, the middle-grade is $46.1 \%$, the primary-grade is $29.1 \%$, the kindergarten is $15.3 \%$, and the high-grade is $9.5 \%$; the number of times of use per week is 2 to 3 times $35.6 \%, 4 \sim 5$ times $20.3 \%$, less 1 time $14.0 \%$, over 8 times $18.2 \%, 6 \sim 7$ times $11.8 \%$; daily use time is $37.7 \%$ less 1 hour, $34.6 \% 1 \sim 2$ hours, $13.4 \% 2 \sim 3$ hours, $8.8 \%$ over 4 hours, $5.5 \% 3$ to 4 hours.

To sum up, this study found that more than $90 \%$ of senior students in Chiayi County played digital games. They started to touch digital games from middle school, and more than $50 \%$ of the use behavior was within 5 times per week and 2 hours per day, it is shown that playing digital games has become a major after-school activity for school children. This phenomenon allows parents and teachers to understand that playing digital games for children has become a trend and cannot be prohibited, but timely remind and pay attention to the use behavior of school children.

\subsection{An Analysis of the Current Status of Digital Games Internet Addiction, Peer Relationship and Learning Attitude for Senior Grade of Elementary Students}

In this study, the digital game internet addiction, according to the hierarchical average of its five major variables, the average of tolerance is up to 2.34 , followed by compulsive, withdrawal, interpersonal problems, time management. In the peer relationship of senior grade of elementary students, based on the stratified average of the two major variables, the average number of friendships is up to 3.15, followed by group identity 2.6. Among senior grade of elementary students' learning attitudes, according to the stratified average of their four major variables, the average of environmental attitude was as high as 3.2, followed by learning method 3.07, learning motivation 3.02, and learning habits 2.68. In terms of the overall level average of each scale variable, the overall level of learning attitude 3.00 is higher than the overall level of peer relationship 2.91 and the overall level of digital games internet addiction 1.98, and the median value of the four-point scale is 2.5 . In order to compare the benchmarks, it is shown that the level of internet games addiction among senior grade of elementary students in Chiayi County is low to medium, the peer relationship is medium to high, and the learning attitude is medium to high.

To sum up, this study found that senior school children in Chiayi County have not yet appeared serious digital game Internet addiction, but pay more attention to tolerance and compulsiveness, because digital games are fun and challenging, making it easy school children can't restrain their desire to play digital games on the online and their time. However, the overall performance of peer relationships and learning attitudes of students is still acceptable, and there is still room for improvement. In particular, group identification and learning habits can be strengthened. This phenomenon is inferred that Chiayi County does not belong to the six capital cities, and the number of students is small. And school children's competition in peer relationships and learning attitudes is weak.

\subsection{Difference Analysis of Digital Games Internet Addiction Among Senior Grade of Elementary Students in Different Background}

The conclusion is found through Tables 4 and 5 in this research: (1) Senior grade of elementary students in different gender have achieved obvious level in withdrawal, compulsiveness, tolerance, time management, and overall levels for digital games internet addiction; male students are significantly higher than female ones. (2) Senior grade of elementary students in different gender have achieved obvious level in friendship sub-level of peer friendship, and female students are significantly higher than male ones. And sixth graders are significantly higher than fifth graders. (3) Senior grade of elementary students in different gender have achieved obvious level in learning habit, learning method, environmental attitude, and overall level, and female students are significantly higher than male ones. (4) Senior grade of elementary students in different grades have achieved obvious level in digital games internet addiction withdrawal and female students are significantly higher than male ones. (5) Senior grade of elementary students in different school location have achieved obvious level in withdrawal, compulsiveness, tolerance, time management, and overall levels of digital game addiction, and the students in Tun District were significantly higher than those in sea area; (6) Senior grade of elementary students in different school location have achieved obvious level in peer relationship and the overall level, for sub-level of relationship, students in sea area are obviously higher than those in Tun District and in mountain area; students in sea area are higher than those in Tun District in overall level. (7) Senior grade of elementary students in different school location have achieved obvious level in method of learning attitude, environmental attitude and overall level, in terms of learning method, students in sea area are higher than those in Tun District, for environmental attitude and the overall level. (8) Different initial use phases have significant differences in the overall level of digital games internet addiction, and the initial use of students in kindergarten stage is significantly higher than 
that of primary grade, middle grade and senior grade. (9) Different weekly use time has achieved significantly different in digital games internet addiction and overall level, and the students who use more than 8 times a week is significantly higher than the students who use less 1 time, $2 \sim 3$ times and $4 \sim 5$ times a week. Students who use 6 to 7 or more times is significantly higher than those within 1 and 2 to 3 times, students who use 4 to 5 times per week is significantly higher than those within 1 time. (10) Different weekly use time has achieved significant differences in the overall level of peer relationship and students who use 2-3 times per week is significantly higher than those who use more than 8 times. (11) Different weekly use time has achieved significantly different in the overall level of learning attitude, students who use less once a week is significantly higher than those who use 6-7 and 8 times. (12) Different daily use time in digital games internet addiction has achieved significantly different, students who use more than 4 hours, 3 to 4 hours, and 2 to 3 hours per day are significantly higher than those who use less than 1 hour and 1 to 2 hours. students who use 1 to 2 hours is significantly higher than those who use less one hour. (13) Different daily use time has achieved significantly different in peer relationship, students who use less one hour and 1 to 2 hours of daily is significantly higher than those who use 4 hours. (14) Different daily use time has achieved significantly different in learning attitude, students who use less 1 hour of daily is significantly higher than those who use 1 to 2 hours, 2 to 3 hours, 3 to 4 hours and over 4 hours, students who use 1 to 2 hours per day is significantly higher than those who use over 4 hours.

To sum up, this study found that senior male students in Chiayi County had different levels of digital addiction in digital games. Except for interpersonal problems, male students were significantly higher than female students, while female students were in a friendship relationship with peer relationships and learning attitudes are significantly higher than boys, except for learning motivation. It is inferred that this phenomenon may be that male school children are more likely to satisfy the sense of achievement and honor by playing through the levels of digital games. Therefore, in general, boys will have a digital game Internet addiction phenomenon than girls. However, because of personality traits, schoolgirls are generally more likely to establish friendship relationships in peer relationships. They also perform better than boys in terms of learning attitude. The study also found that the higher grades of children, the closer the school is to the urban area (Tun District), the earlier the digital games are contacted (kindergartens) and the greater the number and time of use, are more significant differences in digital game Internet addiction. Therefore, these deserve more attention that students with this trait may have the hidden worries of digital game internet addiction in the future. Relatively speaking, the school is farther away from the city (sea area), and the users who use it less frequently have a significant difference in peer relationships and learning attitudes. It may be inferred that the farther the school is from the city, the information is not easy to obtain, and there is no outside Children who are tempted and do not spend too much time in digital games are more likely to have time to manage friendships with their peers and focus on learning performance. Therefore, Hypothesis 1, Hypothesis 2, and Hypothesis 3 of this study are partially supported. 
Table 4. Summary of the differences in the levels of digital games internet addiction, peer relationship, and learning attitude among senior grade of students in different gender, grade, and school location

\begin{tabular}{|c|c|c|c|c|}
\hline $\begin{array}{l}\text { Scale } \\
\text { name }\end{array}$ & $\begin{array}{l}\text { Level } \\
\text { t value/F value }\end{array}$ & $\begin{array}{l}\text { Gender } \\
\mathrm{t} \text { value/Obvious } \\
\text { comparison } \\
\end{array}$ & $\begin{array}{l}\text { Grade } \\
\text { t value/Obvious } \\
\text { comparison }\end{array}$ & $\begin{array}{l}\text { School location } \\
\text { F value/Post-hoc } \\
\text { comparison }\end{array}$ \\
\hline \multirow{10}{*}{$\begin{array}{l}\text { Digital games internet } \\
\text { addiction }\end{array}$} & \multirow[t]{2}{*}{ Withdrawal } & $5.594^{* * *}$ & $-2.577^{*}$ & $9.607 * * *$ \\
\hline & & $\mathrm{A}>\mathrm{B}$ & $\mathrm{B}>\mathrm{A}$ & $\mathrm{C}>\mathrm{B}$ \\
\hline & \multirow[t]{2}{*}{ Obsessive } & $5.558^{* * *}$ & -1.315 & $4.622 * *$ \\
\hline & & $A>B$ & & $\mathrm{C}>\mathrm{B}$ \\
\hline & \multirow[t]{2}{*}{ Tolerance } & $4.348^{* * *}$ & -.984 & $3.839 *$ \\
\hline & & $A>B$ & & \\
\hline & \multirow{2}{*}{ Time management } & $2.708^{* *}$ & .221 & $4.994 * *$ \\
\hline & & $\mathrm{A}>\mathrm{B}$ & & $\mathrm{C}>\mathrm{B}$ \\
\hline & \multirow{2}{*}{ Interpersonal problems } & 1.782 & .656 & $4.576^{*}$ \\
\hline & & & & $\mathrm{C}>\mathrm{B}$ \\
\hline \multirow[t]{4}{*}{ Peer relationship } & \multirow[t]{2}{*}{ Group identity } & -1.275 & -1.027 & 2.268 \\
\hline & & & & n.s. \\
\hline & \multirow[t]{2}{*}{ Friendship } & $-2.052 *$ & -.509 & $8.594 * * *$ \\
\hline & & $\mathrm{B}>\mathrm{A}$ & & $\mathrm{B}>\mathrm{A}, \mathrm{B}>\mathrm{C}$ \\
\hline \multirow[t]{8}{*}{ learning attitude } & \multirow[t]{2}{*}{ Learning motivation } & -1.787 & 1.077 & 2.273 \\
\hline & & & & n.s. \\
\hline & \multirow[t]{2}{*}{ Learning habits } & $-3.097 * *$ & -.095 & 2.473 \\
\hline & & $\mathrm{B}>\mathrm{A}$ & & n.s. \\
\hline & \multirow[t]{2}{*}{ Learning method } & $-3.009 * *$ & -.197 & $5.500 * *$ \\
\hline & & $\mathrm{B}>\mathrm{A}$ & & $\mathrm{B}>\mathrm{C}$ \\
\hline & \multirow[t]{2}{*}{ Environmental attitude } & $-3.105 * *$ & .237 & $7.004 * *$ \\
\hline & & $\mathrm{B}>\mathrm{A}$ & & $\mathrm{B}>\mathrm{A}, \mathrm{B}>\mathrm{C}$ \\
\hline
\end{tabular}

Note. $* * * \mathrm{p}<.001, * * \mathrm{p}<.01, * \mathrm{p}<.05$

1) Gender: A is for male, B is for female; Grade: A is a fifth grade, B is a sixth grade; School location: A is a mountainous area, B is a sea area, $\mathrm{C}$ is a Tun district; Initial use phase: A is a kindergarten, B is primary grade, C is middle grade, D is senior grade; weekly use time: $\mathrm{A}$ is less 1 time, $\mathrm{B}$ is 2 to 3 times, $\mathrm{C}$ is 4 to 5 times, $\mathrm{D}$ is 6 to 7 times, and $\mathrm{E}$ is over 8 times; daily use time: $\mathrm{A}$ is less 1 hour, $\mathrm{B}$ is 1 to 2 hours, $\mathrm{C}$ is 2 to 3 hours, D is 3 to 4 hours, and $\mathrm{E}$ is over 4 hours.

2) n.s. indicates that there is no significant difference in post hoc analysis.

Table 5. Summary of the differences in overall levels of digital games internet addiction, peer relationship, and learning attitude among senior grade of students in different background variables

\begin{tabular}{lllll}
\hline background variables & in overall levels & digital games internet addiction & peer relationship & learning attitude \\
\hline sex & t value & $5.051^{* * *}$ & -1.930 & $-3.408^{* *}$ \\
& significant & $\mathrm{A}>\mathrm{B}$ & & $\mathrm{B}>\mathrm{A}$ \\
grade & t value & -1.150 & -.855 & .372 \\
& significant & & & \\
School location & F value & $8.320^{* * *}$ & $5.738^{* *}$ & $5.644^{* *}$ \\
& Post Hoc & $\mathrm{C}>\mathrm{B}$ & $\mathrm{B}>\mathrm{C}$ & $\mathrm{B}>\mathrm{A}, \mathrm{B}>\mathrm{C}$ \\
First use level & F value & $6.928^{* * *}$ & 1.220 & 1.140 \\
& Post Hoc & $\mathrm{A}>\mathrm{B}, \mathrm{A}>\mathrm{C}, \mathrm{A}>\mathrm{D}$ & $\mathrm{n} . \mathrm{s}$. & $\mathrm{n} . \mathrm{s}$. \\
Usage time every week & F value & $20.640^{* * *}$ & $4.505^{* *}$ & $12.928^{* * *}$ \\
& Post Hoc & $\mathrm{E}>\mathrm{A}, \mathrm{E}>\mathrm{B}, \mathrm{E}>\mathrm{C}, \mathrm{D}>\mathrm{A}, \mathrm{D}>\mathrm{B}$, & $\mathrm{B}>\mathrm{E}$ & $\mathrm{A}>\mathrm{D}, \mathrm{A}>\mathrm{E}, \mathrm{B}>\mathrm{E}, \mathrm{C}>\mathrm{E}$ \\
& & $\mathrm{C}>\mathrm{A}$ & & \\
Usage time every day & F value & $34.369^{* * *}$ & $6.756^{* * *}$ & $16.297^{* * *}$ \\
& Post Hoc & $\mathrm{E}>\mathrm{A}, \mathrm{E}>\mathrm{B}, \mathrm{D}>\mathrm{A}, \mathrm{D}>\mathrm{B}, \mathrm{C}>\mathrm{A}$, & $\mathrm{A}>\mathrm{E}$ & $\mathrm{A}>\mathrm{B}, \mathrm{A}>\mathrm{C}, \mathrm{A}>\mathrm{D}, \mathrm{A}>\mathrm{E}$, \\
\hline
\end{tabular}

Note. ${ }^{* * *} \mathrm{p}<.001,{ }^{* *} \mathrm{p}<.01,{ }^{*} \mathrm{p}<.05$.

Same as Note 1 in Table 6; Note 4: Same as Note 2 in Table 6.

4.4 Correlation Analysis of Senior Grade of Students' Digital Games Internet Addiction, Peer Relationship and Learning Attitude

From the related analysis of Table 6 and Table 7, we can find the following findings: (1) There is no relation between withdrawal and group identity, and senior grade of students have low level of negative correlation in 
sub-level and the overall level of the digital games internet addiction sub-level and overall level of the learning attitude. (2) Senior grade of students have low level of negative correlation in sub-level and the overall level of the digital games internet addiction and sub-level and overall level of the learning attitude. (3) Senior grade of students have middle level of positive correlation in sub-level and the overall level of the the peer relationship and sub-level and the overall level of the learning attitude. (4) Senior grade of students have a close relations between the peer relationship and learning attitude in digital games internet addiction, peer friendship and the product-moment correlation analysis of sub-level and overall level of the learning attitude. (5) Senior grade of students have a negative relations between the time management and friendship, in digital games internet addiction, sub-level of the product-moment correlation analysis of the peer relationship and learning attitude; having a negative correlation between the time management and learning method, having a positive correlation between the friendship and environment attitude. According to the results of research, it means that students take a long time to play games may alienate their friends and cause a negative influence on the review, preparation and learning methods of the school. In addition, the better the friendship between the students, the better the overall learning effect between the teacher and the classmates.

In summary, this study is supported by Hypothesis 4. Through the verification of the senior students in the elementary school in Chiayi County, it is shown that when more senior students play digital games, they may not be able to concentrate on teacher teaching and curriculum learning, and then, much more affect learning attitude. When the friendship between senior students and their peers is better, it may bring a happy mood. With the help of peers, they will also bring positive feedback on their learning attitude.

Table 6. Correlation analysis table of the product-moment between peer friendship and learning attitude of digital addiction in digital games internet addiction among senior grade of students

\begin{tabular}{|c|c|c|c|c|c|c|}
\hline Items & Withdrawal & Obsessive & Tolerance & $\begin{array}{l}\text { Time } \\
\text { Management }\end{array}$ & $\begin{array}{l}\text { Interpersonal } \\
\text { problems }\end{array}$ & $\begin{array}{l}\text { Digital games internet } \\
\text { addiction (Overall Level) }\end{array}$ \\
\hline Group identity & -.062 & $-.115^{* *}$ & $-.125^{* *}$ & $-.114^{* *}$ & $-.115^{* *}$ & $-.131^{* *}$ \\
\hline Friendship & $-.155^{* *}$ & $-.182^{* *}$ & $-.141^{* *}$ & $-.274^{* *}$ & $-.243^{* *}$ & $-.237^{* *}$ \\
\hline $\begin{array}{l}\text { Peer relationship } \\
\text { (Overall level) }\end{array}$ & $-.128^{* *}$ & $-.182^{* *}$ & $-.152^{* *}$ & $-.228^{* *}$ & $-.210^{* *}$ & $-.214^{* *}$ \\
\hline Learning motivation & $-.228^{* *}$ & $-.240^{* *}$ & $-.161^{* *}$ & $-.248^{* *}$ & $-.138^{* *}$ & $-.250^{* *}$ \\
\hline Learning habit & $-.253^{* *}$ & $-.291^{* *}$ & $-.293^{* *}$ & $-.221^{* *}$ & $-.168^{* *}$ & $-.302^{* *}$ \\
\hline Learning method & $-.261^{* *}$ & $-.310^{* *}$ & $-.250^{* *}$ & $-.317^{* *}$ & $-.227^{* *}$ & $-.332^{* *}$ \\
\hline Environmental attitude & $-.216^{* *}$ & $-.257^{* *}$ & $-.217^{* *}$ & $-.290^{* *}$ & $-.225^{* *}$ & $-.292^{* *}$ \\
\hline $\begin{array}{l}\text { learning attitude } \\
\text { (Overall level) }\end{array}$ & $-.302^{* *}$ & $-.345^{* *}$ & $-.286^{* *}$ & $-.338^{* *}$ & $-.236^{* *}$ & $-.369^{* *}$ \\
\hline
\end{tabular}
Note. ${ }^{* *} \mathrm{p}<.01$.

Table 7. Correlation analysis table of product-moment between peer relationship and learning attitude of senior grade of students

\begin{tabular}{llllll}
\hline Items & $\begin{array}{l}\text { Learning } \\
\text { motivation }\end{array}$ & Learning habit & Learning method & $\begin{array}{l}\text { Environmental } \\
\text { attitude }\end{array}$ & $\begin{array}{l}\text { learning attitude } \\
\text { (Overall level) }\end{array}$ \\
\hline Group identity & $.289^{* *}$ & $.409^{* *}$ & $.340^{* *}$ & $.338^{* *}$ & $.431^{* *}$ \\
Peer relationship & $.419^{* *}$ & $.401^{* *}$ & $.460^{* *}$ &. $\mathbf{. 5 6 1}^{* *}$ & $.577^{* *}$ \\
Peer relationship (Overall level) & $.409^{* *}$ & $.462^{* *}$ & $.461^{* *}$ & $.522^{* *}$ & $\mathbf{. 5 8 1}^{* *}$ \\
\hline Note $^{* * *} \mathrm{p}<.01$ & & & &
\end{tabular}

\subsection{The Predictive Capacity of Digital Games Internet Addiction and Peer Relationship on Learning Attitude}

Stepwise multiple regression analysis from Table 8 to 12 and find out the following standardized regression formulas: 1) Learning attitude at the overall level $=.436 \times$ friendship $+(-.214) \times$ obsessiveness $+.165 \times$ group identity $+(-.125) \times$ time management $+.082 \times$ interpersonal problems; 2) Learning motivation $=.339 \times$ friendship $+(-.091) \times$ obsessiveness $+.089 \times$ group identity $+(-.103) \times$ withdrawal; 3) Study habit $=.252$ $\times$ group identity $+(-.171) \times$ tolerance $+.236 \times$ friendship $+(-.146) \times$ compulsiveness $+.079 \times$ interpersonal problems; 4) Learning method $=.329 \times$ friendship $+(-.165) \times$ compulsiveness $+.130 \times$ group identification + $(-.114) \times$ time management; 5) Environmental attitude $=.518 \times$ friendship $+(-.116) \times$ compulsiveness + $(-.080) \times$ time management. 
Table 8. Stepwise multiple regression table of digital games internet addiction and peer relationship to learning attitude of senior grade of students

\begin{tabular}{|c|c|c|c|c|c|c|c|}
\hline \multirow[t]{2}{*}{ Variable order } & \multirow[t]{2}{*}{$\mathrm{R}$} & \multirow[t]{2}{*}{$\mathrm{R}^{2}$} & \multirow{2}{*}{$\begin{array}{l}\text { Increment } \\
\left(\Delta \mathrm{R}^{2}\right)\end{array}$} & \multirow{2}{*}{$\begin{array}{l}\text { Beta } \\
(\beta)\end{array}$} & \multirow[t]{2}{*}{ F value } & \multicolumn{2}{|c|}{ Collinearity statistics } \\
\hline & & & & & & Tolerance & VIF \\
\hline Friendship & .577 & .333 & .333 & .436 & $341.432^{* * *}$ & .664 & 1.506 \\
\hline Compulsiveness & .627 & .393 & .060 & -.214 & $220.637^{* * *}$ & .601 & 1.664 \\
\hline Group identity & .641 & .411 & .018 & .165 & $158.376^{* * *}$ & .709 & 1.410 \\
\hline Time management & .645 & .416 & .005 & -.125 & $120.995^{* * *}$ & .508 & 1.968 \\
\hline Interpersonal problems & .648 & .420 & .004 & .082 & $98.186^{* * *}$ & .562 & 1.779 \\
\hline
\end{tabular}
Note. $\mathrm{p}^{* * *<.001 \text {. }}$

Table 9. Stepwise multiple regression table of digital games internet addiction and peer relationship to learning motivation of senior grade of students

\begin{tabular}{|c|c|c|c|c|c|c|c|}
\hline \multirow[t]{2}{*}{ Variable order } & \multirow[t]{2}{*}{$\mathrm{R}$} & \multirow[t]{2}{*}{$\mathrm{R}^{2}$} & \multirow{2}{*}{$\begin{array}{l}\text { Increment } \\
\left(\Delta \mathrm{R}^{2}\right)\end{array}$} & \multirow{2}{*}{$\begin{array}{c}\text { Beta } \\
(\beta)\end{array}$} & \multirow[t]{2}{*}{ F value } & \multicolumn{2}{|c|}{ Collinearity statistics } \\
\hline & & & & & & Tolerance & VIF \\
\hline Friendship & .419 & .176 & .176 & .339 & $145.712^{* * *}$ & .699 & 1.430 \\
\hline Compulsiveness & .451 & .204 & .028 & -.091 & $87.206^{* * *}$ & .462 & 2.164 \\
\hline Group identity & .457 & .209 & .005 & .089 & $59.805^{* * *}$ & .709 & 1.410 \\
\hline Withdrawal & .462 & .214 & .005 & -.103 & $46.153^{* * *}$ & .467 & 2.142 \\
\hline
\end{tabular}

Note. $\mathrm{p}^{* * *<.001}$

Table 10. Stepwise multiple regression table of the relationship between senior grade of students' digital games internet addiction and peer relationship to learning habit

\begin{tabular}{|c|c|c|c|c|c|c|c|}
\hline \multirow[t]{2}{*}{ Variable order } & \multirow[t]{2}{*}{$\mathrm{R}$} & \multirow[t]{2}{*}{$\mathrm{R}^{2}$} & \multirow{2}{*}{$\begin{array}{l}\text { Increment } \\
\left(\Delta \mathrm{R}^{2}\right)\end{array}$} & \multirow{2}{*}{$\begin{array}{l}\text { Standardized regression } \\
\text { coefficient }(\beta)\end{array}$} & \multirow[t]{2}{*}{ F value } & \multicolumn{2}{|c|}{ Collinearity statistics } \\
\hline & & & & & & Tolerance & VIF \\
\hline Group identity & .409 & .168 & .168 & .252 & $137.497^{* * *}$ & .711 & 1.407 \\
\hline Tolerance & .476 & .227 & .059 & -.171 & $100.052^{* * *}$ & .548 & 1.825 \\
\hline Friendship & .515 & .265 & .038 & .236 & $81.880^{* * *}$ & .681 & 1.469 \\
\hline Compulsiveness & .522 & .273 & .008 & -.146 & $63.771^{* * *}$ & .506 & 1.976 \\
\hline Interpersonal problems & .526 & .277 & .004 & .079 & $52.009^{* * *}$ & .658 & 1.520 \\
\hline
\end{tabular}

Table 11. Stepwise multiple regression table of relationship between senior grade of students' digital games internet addiction and learning method

\begin{tabular}{|c|c|c|c|c|c|c|c|}
\hline \multirow[t]{2}{*}{ Variable order } & \multirow[t]{2}{*}{$\mathrm{R}$} & \multirow[t]{2}{*}{$\mathrm{R}^{2}$} & \multirow{2}{*}{$\begin{array}{l}\text { Increment } \\
\left(\Delta \mathrm{R}^{2}\right)\end{array}$} & \multirow{2}{*}{$\begin{array}{l}\text { Standardized regression } \\
\text { coefficient }(\beta)\end{array}$} & \multirow[t]{2}{*}{ F value } & \multicolumn{2}{|c|}{ Collinearity statistics } \\
\hline & & & & & & Tolerance & VIF \\
\hline Friendship & .460 & .211 & .211 & .329 & $182.807^{* * *}$ & .669 & 1.495 \\
\hline Compulsiveness & .514 & .264 & .053 & -.165 & $122.397^{* * *}$ & .649 & 1.542 \\
\hline Group identity & .524 & .275 & .010 & .130 & $85.935^{* * *}$ & .710 & 1.409 \\
\hline Time management & .532 & .283 & .008 & -.114 & $67.005^{* * *}$ & .621 & 1.611 \\
\hline
\end{tabular}

Note, $\mathrm{p}^{* * *}<.001$

Table 12. Stepwise multiple regression summary table for senior's grade of students' digital games internet addiction and peer relationship to Environmental attitudes

\begin{tabular}{|c|c|c|c|c|c|c|c|}
\hline \multirow[t]{2}{*}{ Variable order } & \multirow[t]{2}{*}{$\mathrm{R}$} & \multirow[t]{2}{*}{$\mathrm{R}^{2}$} & \multirow{2}{*}{$\begin{array}{l}\text { Increment } \\
\left(\Delta \mathrm{R}^{2}\right)\end{array}$} & \multirow{2}{*}{$\begin{array}{l}\text { Standardized regression } \\
\text { coefficient }(\beta)\end{array}$} & \multirow[t]{2}{*}{ F value } & \multicolumn{2}{|c|}{ Collinearity statistics } \\
\hline & & & & & & Tolerance & VIF \\
\hline friendship & .561 & .315 & .315 & .518 & $313.902^{* * *}$ & .924 & 1.082 \\
\hline compulsiveness & .583 & .340 & .025 & -.116 & $175.428^{* * *}$ & .653 & 1.532 \\
\hline Time Management & .586 & .344 & .004 & -.080 & $118.854^{* * *}$ & .625 & 1.601 \\
\hline
\end{tabular}

Note. $\mathrm{p}^{* * *<.001}$

In summary, this study Hypothesis 5 is supported, there are five independent variables between digital games internet addiction and peers among senior grade of students to predict the "learning attitude", which can explain $42.0 \%$ of the total variation and rank from high to low as "friendship" “, "compulsiveness" ,"group identity", "time management" and "interpersonal problems". The $\beta$ value of "friendship" is the positive and largest, which can explain $33.3 \%$ of all, because the next "compulsiveness" $\beta$ value is negative, which means that the higher the 
friendship in the peer relationship in the senior grade students in Chiayi County, the better the performance of learning attitude. The more school children play digital games can't restrain the impulse to the Internet, the worse their attitude towards learning performance. In addition, the prediction on the sub-level of "learning motivation", "learning method", and "environment attitude" have the highest $\beta$ value of "friendship", which can explain all $17.6 \%$; the prediction on the sub-level of "learning habit" layer has the highest $\beta$ value of "group identity", which can explain all is $16.8 \%$; The results stand out the prediction on the sub-level of "learning attitude" and "environment attitude", the $\beta$ value of "friendship" are the all highest and also there is a positive influence. It is inferred that this phenomenon should be when the friendship of school children is increased, and the better the intimacy and interaction, the better the surrounding environment of learning will lead to a good environmental attitude. In addition, in the digital addiction to games, "compulsiveness" has predictive power and negative influence on the overall level and all levels of learning attitudes. It is inferred that this phenomenon may be due to the poor self-discipline of the senior grade elementary school children due to their young age, and digital games are constantly emerging, becoming a topic of discussion among peers, triggering schoolchildren's desire to surf the Internet, and less restrained urge to play to be easily became an important factor affecting learning attitudes.

\section{Conclusion and Suggestion}

\subsection{Conclusion}

Based on the results of empirical analysis, this study summarizes as follows: the ratio of senior grade of students who currently plays digital games in the Chiayi County elementary school is as high as $90 \%$, and most of them began to use the digital games from the middle school level. They are used five times a week, and there are the most children within 2 hours per day. At present, there are no digital game addictions among school children. The peer relationship is at the middle-to-up level, with "friendship relationship" being the highest, the learning attitude is at the middle-up level, and the "environmental attitude" is the highest. Chiayi County elementary school Seniors' students with different background variables such as "sex", "school location", "initial use stage", "weekly use", "daily use time" have significant Differences on the digital games Internet addiction; And also, in peer relationships between "school location", "weekly usage", and "daily use time"; "gender", "school location", "weekly use", "daily use" "Using time" has a significant difference in learning attitude. In Chiayi County, elementary school children's addiction on the digital games Internet addiction had a low negative correlation between peer relationship and learning attitude, while peer relationship and learning attitude showed a moderate positive correlation. Finally, the study found that the digital games Internet addiction and peer relationships can effectively predict learning attitudes, which can explain $42.0 \%$ of the total variation, and the coefficient, of which "friendship" and "compulsiveness" are more predictive.

Looking at the results of this research, it can bring some contributions to the academic research of primary education. Through this research, it is confirmed that digital games have penetrated into the daily lives of school children and become an activity that cannot be ignored. However, digital games Internet addiction has not yet been constituted in senior elementary school students in Chiayi County students. Studies have also confirmed that senior-school children have strong correlations and positive predictive power with "friendship" in their learning attitudes in peer relationships, while "compulsive" negative predictive power in digital game internet addiction. This phenomenon can be used as an important reference when elementary school teachers and parents educate children. This study found that "school location", "weekly usage", and "daily use time" among the basic variables of school children can bring significant differences in digital games internet addiction, peer relationships, and learning attitudes. This discovery will serve as a follow-up in-depth investigation. Finally, this study attempts to use digital games internet addiction, combined with peer relationships and learning attitudes to conduct research, which is in line with the current educational scene and fills the gaps in related research. Its research results will have its value.

\subsection{Suggestions}

Based on the results of this study, the following suggestions are made for reference to parents, teachers, and follow-up researchers:

1) Parents and teachers shall regulate and publicize properly the number of times a week and daily time for students to play digital games. The study found that more than $90 \%$ of students play digital games, 2 to 3 times a week for $35 \%$ and 4 to 5 times for $20 \%$, less 1 hour of use more than $37 \%, 1$ to 2 hours over $34 \%$, and less $10 \%$ of students play digital games for more than 4 hours, and "weekly use time" and "daily use time" have significant differences in digital games internet addiction, peer relationship and learning attitude; male students have more obviously different than female ones in digital games internet addiction. Therefore, it is recommended 
that teachers and parents shall regulate and try to control daily use for no more than 1 hour and limit less than 5 times a week. It can increase family outdoor activities, reduce opportunities for students to use, and pay more attention to the behavior of male students playing digital games.

2) Teachers shall make good use of class management and teaching activity design to increase the peer relationship and learning attitude of students. The study found that the peer relationship and learning attitude of Chiayi County elementary school students are at the middle and upper level, it still has room to improve. The study found that the peer relationship can predict the learning attitude effectively, and there is a moderate positive correlation between them. Therefore, teachers can make good use of class management and teaching activity design to add group report and apply social platforms such as Line and google classroom to encourage senior grade of students to express their opinions, increase opportunity for student interaction, and enhance learning attitude through peer cooperation and improve teamwork efficiency.

3) Parents and teachers shall pay attention to the tolerance of student's digital game internet addiction and employ appropriate strategies to prevent them from being a highly potential addiction in the future.

The research found that elementary school students in Chiayi County are at a low-to-medium level of digital games internet addiction. It will also increase, so it is suggested that parents and teachers can " develop secondary expertise or interests of students actively, so that students won't have time to play digital games for addiction reduction", "find highly addicted people at home and in the class, consult with individual appropriately to promote learning attitude efficiency at class", "increase diversified and appropriate leisure activities to create busy and fulfilling lives", "limit and regulate time appropriately and foster the self-control of ability for students" in order to prevent from digital games internet addiction since from elementary school period.

4) Follow-up research can include "qualitative research" in research methods, "across county and city research" and "comparative research of primary, middle, and senior grade of students" in research objects. This research only adopts single county, city, and senior grade of students to explore and discuss with quantitative research. Therefore, the conclusions of research will not be applicable to all senior grades of students. It is recommended that researchers can expand the scope of research to increase research contribution.

\section{References}

Chang, C.-H. (1992). Zhang's Dictionary of Psychology (Revised ed.). Taipei City: Donghua Bookstore.

Chang, T.-J. (1997). Education Administration. Taipei City: Wunan Book Publishing Company.

Chen, S.-H. (1999). Research on the Integration of Phenomenon of Computer and Internet Addiction of Chinese Students (Sub-plan 1: The Psychopathology of Internet Addiction Phenomenon 2/2). Special Research Project of National Science Committee of the Executive Yuan.

Chen, S.-H., Weng, L.-C., Su, Y.-J., Wu, H.-M., \& Yang, P.-F. (2003). Compilation of Chinese Internet Addiction Scale and Psychometric Characteristics. Chinese Journal of Psychology, 1(1), 279-294. https://doi.org/10.1037/t44491-000

Chen, Y.-Y. (2015). An Action Study of Balanced Reading Teaching on English Learning Motivation. Learning Attitude and Learning Effectiveness of 5th Grade Primary School Students, Tainan City: National Tainan University Doctoral Program in Curriculum and Teaching, Department of Education.

Chin, M.-C. (1992). Study on the relationship between the management mentality of high school teachers, the beliefs of internal and external control of students, and the study habits and attitudes of students. Education and Psychological Research, 15, 129-171.

Chiu, P.-Y. (2011). Study on the phenomenon of Internet addiction among senior students in elementary school. Kaohsiung: Department of Industrial Science and Technology Education, National Kaohsiung Normal University, Master's Thesis.

Goldberg, I. (August 24, 2016). Internet Addiction Disorder. Retrieved from http://www.rider.edu/ suler/psycyber/supportgp.html

Griffiths, M. D. (1995). Technological addictions, Clinical Psychology Forum. Division of Clinical Psychology of the British Psychol. Soc.

Hartup, W. W. (1983). Peer relations. In E. M. Hetherington (Ed.), Handbook of child psychology (pp. 103-196). New York.

Huang, C.-C. (2011). Study on Learning Attitude and Learning Effectiveness of Senior and Junior High School Students of New Immigrants and Non-New Immigrants in New Taipei City. Taipei: National Institute of 
Curriculum and Teaching, Taipei University of Education, Master's Thesis.

Huang, C.-K. (2003). Relevant Research on Perceived Class Atmosphere, Learning Attitude and Creative Tendency of National Primary School Children. Chiayi City: National Chiayi University Institute of National Education, Master's Thesis.

Huang, Q. J. (2006). Study on Learning Attitudes and Achievements of New Immigrant Children of Hsinchu National Primary School. Hsinchu City: Hsinchu Education University Master's Class, Master's Thesis.

Huang, Y.-H. (2017). Research on Internet Addiction, Interpersonal Relations, and Physical and Mental Health of Junior High School Students (Taking Kaohsiung Private Lizhi Middle School as an example). Master of Information Management, Yishou University.

Santrock, J. W. (1988). Children. Dubuque, IA: WM. C.

Kevin, D. (1995). Developmental social psychology: From infancy to old age. Blackwell Publishing.

Kimberly, S. Y. (1998). Internet addiction: The emergence of a new clinical disorder. Cyber Psychology \& Behavior, 1(3), 237-244. https://doi.org/10.1089/cpb.1998.1.237

Kimberly, S. Y. (2004). Internet addiction: A new clinical phenomenon and its consequences. American Behavioral Scientist, 48(4), 402-415. https://doi.org/10.1177/0002764204270278

Keith, J. A. (2001). Internet use among college students: An exploratory study. Journal of American College Health, 50(1), 21-26. https://doi.org/10.1080/07448480109595707

Berk, L. E. (1997). Child development. Boston: Allyn \& Bacon.

Lewis, M. E., \& Leonard, A. R. (1975). Friendship and peer relations. John Wiley \& Sons.

Liang, L.-Y. (2007). Discussion on the Research on the Types of Leisure Activities, Learning Attitudes and Internet Addiction of Primary School Children in Chiayi District. Chiayi County: Institute of Information Management, Private Nanhua University.

Lin, S.-H. (2000). Research on the Relationship between Self-concept and Peer Peer of Middle School Students. Pingtung City: Institute of Educational Psychology and Counselling, National Pingtung Teachers College.

Liu, M.-Y. (2014). Study on Internet addiction among middle school students, peer relationship and sexual attitude. Chiayi City: Institute of Counselling and Counseling, National Chiayi University, Master's Thesis.

Liu, W.-S. (2004). Research on Internet Addiction and Internet Literacy of Primary School Children. Tainan City: Master's Class, Department of Education, National Tainan University.

Lu, F.-Y. (2011). Effects of Internet Use Behavior on Peer Relationships-A Case Study of Senior School Children in Elementary Schools in the Coastal Area of Yunlin County. Tainan City: Institute of Information and Communication, Corning University, Master's Thesis.

National Development Commission. (2017 July). 2017 Internet Addiction Research Report. R \& D Marketing Research Co., Ltd. Retrieved December 5, 2019, from https://ws.ndc.gov.tw/Download.ashx?u=LzAwMS9hZG1pbmlzdHJhdG9yLzEwL2NrZmlsZS83MjV1OTB1 OC1iZWVjLTQ0NzgtODA0MC1hNjBIYzEyYjMwNDkucGRm\&n=MTA25bm057ay6Lev5rKJ6L\%2B3Ln $\mathrm{BkZg} \% 3 \mathrm{D} \% 3 \mathrm{D}$

Rosenberg, M. J., \& Hovland, C. I. (Eds.) (1960). Attitude organization and change. Yale University Press.

Shih, Y.-H. (2019). Research on Internet Addiction Risk Factors, Internet Addiction and Mental Health Problems of College Students. Master of Counselling and Counseling, National Changhua Normal University.

Su, C.-Y. (2018). Research on Personality Traits, Learning Attitude and Mathematical Learning Achievement. Kaohsiung City: Master Class of School of Management, Yishou University.

Taiwan Network Information Center. (2019). 2018 Taiwan Network Report. Chuangshi Market Research Consulting Co., Ltd. Retrieved December 5, 2019, from https://www.twnic.net.tw/doc/twrp/201812e

Tsai, C.-H. (2011). Research on Attitudes to Study and Internet Addiction in Senior High School Students in Kaohsiung. Kaohsiung City: Institute of Industrial Science and Technology Education, Kaohsiung Normal University, Master Essay.

Tsai, P.-C. (2005). Research on Internet Use Behavior, Interpersonal Relationships, and Internet Addiction: A Case Study of Senior School Children in Chiayi City. Chiayi City: Institute of Information Management, Nanhua University, Master's Thesis. 
Weng, C.-Y. (2014). Research on the Impact of Online Games Addiction to Physical and Mental Health and Learning Attitude of Senior Elementary School Students: Taking Miaoli County as an example. Changhua County: Master's Class, School of Management, Daye University.

Wikipedia. (2019). Definition of digital games in the digital content industry. Retrieve December 5, 2019, from https://en.wikipedia.org/wiki/\%E6\%95\%B8\%E4\%BD\%8D\%E5\%85\%A7\%E5\%AE\%B9\%E7\%94\%A2\%E6 $\% \mathrm{~A} 5 \% \mathrm{AD}$

Wu, S.-C. (2016). Study on the Relationship between Learning Motivation, Learning Attitude and Learning Effectiveness of Senior Students in Penghu Elementary School. Tainan City: National Tainan University's Master's Degree in Curriculum and Teaching.

Wu, T.-L. (2013). Analysis of the Functions Needed by Beginners of the Digital Game Industry. Taipei City, National Taiwan Normal University Human Resources Master's Degree Program, Master's Thesis.

Xiao, S. L. (2019). Study of learning achievement, interpersonal relationship and internet addiction, Master of On-the-job Class. Department of Business Management, Asian University.

Yang, Y. -C., \& Liang, C.-Y. (2001). Internet Addiction and Its Research Needs. Audiovisual Education Bimonthly, 43(3), 2-12.

Yeh, C.-H. (2011). Research on the Relationship between Online Peer, Self-identity and Gender of Senior Students in Elementary Schools-Taking Participants in Online Games as Examples. Pingtung City: National Pingtung University of Education, Master of Social Sciences Teaching, Master's Thesis.

\section{Copyrights}

Copyright for this article is retained by the author, with first publication rights granted to the journal.

This is an open-access article distributed under the terms and conditions of the Creative Commons Attribution license (http://creativecommons.org/licenses/by/4.0/). 